\title{
STRUCTURE OF THE FLORAL PARTS OF Crocus vernus (L.) Hill
}

\section{Elżbieta Weryszko-Chmielewska, Mirosława Chwil}

\author{
Department of Botany, University of Life Sciences in Lublin, Akademicka 15, 20-934 Lublin, Poland, \\ e-mail: elzbieta.weryszko@up.lublin.pl
}

Received: 24.10.2011

\begin{abstract}
In the climatic conditions of Lublin, Crocus vernus blooms from the third decade of March until the third decade of April. The flowers live for 3-4 days. Micromorphological investigations of the tepals and perianth tube as well as of the stamens and pistil were carried out using scanning electron microscopy. The anatomical features of the perianth segments and flower stem were examined with the use of light and fluorescence microscopy. Pollen grains were observed under a light microscope. It was found that the adaxial and abaxial epidermal cells formed papillae in the middle and lower part of the tepals. Much smaller papillae are formed in the upper region of the perianth tube. Elongated non-glandular and glandular trichomes, with spherical protrusions at the tip, are found at the base of the filaments. The filaments are distinguished by epidermal cells with a longitudinally striated cuticle and by the presence of papillae of varying number and size. The cylindrical papillae on the stigma of the pistil are covered by a wrinkled cuticle. The style is surrounded by the perianth tube along a significant length. A narrow space is formed between these organs, and it is filled by the nectar. Stylar channels are found in the style. We observed calcium oxalate crystals and numerous plastids in the parenchymal cells surrounding these channels. Inaperturate, spherical pollen grains are covered by numerous tryphine (or pollenkitt) droplets. This paper also discusses the functions of the papillae found in the epidermis of the perianth and filaments.
\end{abstract}

Key words: Crocus vernus, flowers, perianth, stamen, pistil, trichomes, papillae, micromorphology, anatomy

\section{INTRODUCTION}

The genus Crocus L. (Iridaceae) includes 80-100 species of perennial plants with an underground bulb (corm) covered with scales (M a b b e r ly, 1997; S zweykowscy, 2003). Most of them are native to Central Europe (O s zkin is, 1994). Crocuses are considered to be ornamental, bee forage, spice, dye-producing, cosmetic, and medicinal plants ( $\mathrm{M} \mathrm{a} \mathrm{u}$ rizi o and Graf 1, 1969; P od bielk ow ski, 1980, 1992; Chichiricco, 1990; J aroszyńska, 1992; Kohlmünzer, 1997; Strzelecka and Kowalski, 2000; Kołtowski, 2006; Arslan et al. 2009; $\mathrm{Namin}$ et al. 2010; Makhlouf et al. 2011).

Crocuses often grow in early spring pushing up through a layer of snow (P od bi e lk ow s ki, 1980; $\mathrm{Zhang}$ and Tan, 2009). They are one of the first sources of nectar and pollen for insects (M a u ri z i o and Graf 1, 1969; M e hr 1, 1987; J a r o s z y ń s ka, 1992; D a 1 b y , 2000; K o ł t ow s k i , 2006). Depending on the altitude of occurrence, these plants provide large amounts of pollen from March until May. It has been calculated that a single crocus (Crocus sp.) flower produces $1.9 \mathrm{mg}$ of pollen (M a urizio and Graf 1, 1969). In the climatic conditions of Poland, pollen weight per flower in various species of the genus Crocus ranges 6.2-24.6 mg, with its average value equal to $15 \mathrm{mg}$ (J a r o s z y ń s k a, 1992). Foraging on crocus pollen, bees form large (about $8.3 \mathrm{mg}$ ) yellow to orange pollen loads. The pollen of crocus plants is collected by insects throughout the whole day, with peak foraging activity at noon and in early afternoon hours. The pollen of this taxon is included in the first-class group on account of its protein content (M a u ri zio and $\mathrm{Gr}$ a f 1, 1969).

Due to their intense aroma and spicy flavour, the stigmas of the pistil in crocus are used as a very costly seasoning (R e jew ski, 1992). The large orange stigmas also provide raw material containing crocin, which is used to colour food products and cosmetics as well as to dye fabrics (H lava, 1984; P od bie lk owski, 1992; Kohlmünzer, 1997; Radjabi a n et al. 2001; Morag a et al. 2004). 
Crocus vernus (L.) Hill comprises a large group of cultivars with various colours of the flower (Mölzer, 1983). The plants reach a height of 10-12 $\mathrm{cm}$ ( $\mathrm{Kra}$ u s e, 2002). The perianth is composed of a long tube $(2.5-15 \mathrm{~cm})$ and 6 tepals with a length of $1.5-5.5 \mathrm{~cm}$ (R u t k o w s k i, 2008). In the flower, there are three stamens, a single three-parted pistil with an inferior ovary, and a long style terminated with three yellow stigmas. The fruit is a capsule which is produced by the ovary hidden in the ground; the capsule is borne above the ground by the elongating flower stalk (Piękoś-Mirkowa and Mirek, 2007).

The aim of the study was to investigate the ecological features and structure of some floral parts of spring crocus (Crocus vernus (L.) Hill). The present paper compares the micromorphology of the epidermis covering the perianth, pistil, and stamens as well as it presents the anatomical structure of the tepals and flower stalk. Special attention is paid to the varying structure of the papillae found on different parts of the perianth.

\section{MATERIALS AND METHODS}

The present study investigated the ecological features of flowers and the structure of some floral parts of spring crocus (Crocus vernus (L.) Hill). Plant material came from the Botanical Garden of the Maria $\mathrm{Cu}-$ rie-Skłodowska University in Lublin. To perform live cell staining and to fix the plant material, the following parts of the flower were sampled at full flowering: perianth tube and tepals, stamens, ovary, style, stigma, and flower stem. The features of the flower structure and the micromorphology of the epidermis of the selected flower parts were observed using stereoscopic, light, fluorescence, and scanning electron microscopy.

Stereoscopic microscopy. Preliminary observations of the selected floral parts, their measurements, and photographic documentation were made with an SMT 800 stereoscopic microscope.

Light microscopy. The structure of the tissues of the flower stem, ovary, perianth, and style was analysed in cross sections under a Nikon Eclipse 400 light microscope. We also observed pollen grains, the papillae of the perianth and stigma as well as the trichomes growing at the boundary of the tube and the free perianth segments near the point of adnation of the filaments. The presence of lipid substances in the cells was examined with Sudan III staining. Pollen viability was determined using Belling's acetocarmine. The pollen grain diameter was determined on the basis of measurements of 500 pollen grains.

Semi-thin sections. A part of alcohol-dehydrated specimens (the description is included in the section on SEM) was used to prepare semi-thin sections. After the portions of the selected floral parts were embedded in Spurr's low viscosity resin, 0.8-1 $\mu \mathrm{m}$ thick sections were obtained by means of a Reichert Ultracut S microtome. The cross-sections were stained with toluidine blue or ruthenium red.

Fluorescence microscopy. Observations of the structure of the tissues, with special attention to the papille and the location of secretion in the tepals, were carried out under a NIKON Eclipse 90i fluorescence microscope. The specimens prepared from fresh and resin-embedded material (cross sections) were examined using a filter set: blue DAPI Ex = 340-380 nm, BA $=435-485 \mathrm{~nm}$; red TRITC Ex = $540 / 25 \mathrm{~nm}, \mathrm{BA}=605 / 55 \mathrm{~nm}$; green FITC $\mathrm{Ex}=$ 465-495 and BA 515-555 nm.

Scanning electron microscopy. The micromorphology of the epidermis of the stigma and style, filament and anther, tube and tepals as well as the structure of the tissues of the perianth tube and style were analysed under a Tescan Vega II scanning electron microscope.

The plant material was fixed in $4 \%$ glutaraldehyde in $0.1 \mathrm{M}$ phosphate buffer with a $\mathrm{pH}$ of 7.0 for 4 hours at room temperature. Next, it was dehydrated in increasing alcohol concentrations. After rinsing in acetone series, the plant material was critical-point dried in liquid $\mathrm{CO}_{2}$ and sputter-coated with gold using a CS 100 Sputter Coater.

\section{RESULTS}

\section{Morphological features of the flower}

Under the conditions prevailing in Lublin, Crocus vernus blooms from the third decade of March until the third decade of April. The flower life span is 3-3.5 days. The perianth length reaches $13-15 \mathrm{~cm}$. The perianth tube with a diameter of 3-4 $\mathrm{mm}$ is about $l$ ' of the length of the whole perianth and its lower part is extending down into the ground. The perianth tube is surrounded by a long membranous leaf. The orange coloured androecium and the upper part of the style are surrounded by six perianth lobes arranged in a cup-like formation (Fig. 1A).

The filaments of the three stamens, 21-30 mm long, are attached to the upper part of the perianth tube (Fig. 1B). The anther length is 10-17 mm. The ovary of the pistil, 6-10 $\mathrm{mm}$ in height, grows under the ground on a stalk with a length of 5-6 cm, which is a stem with a cross section close to a pentagon (Fig. 1C). The style length is $10-13 \mathrm{~cm}$.

\section{Micromorphology and the structure of the flower parts}

Flower stalk

The flower stalk contains 9-12 vascular bundles (Fig. 1D). It is covered by small epidermal cells with 
cutinized outer walls, which was clearly visible after the application of toluidine blue (Fig. 1E) and after treatment with Sudan III (Fig. 1 F). The subepidermal layer in the stalk is formed by angular collenchyma. Very large intercellular spaces were observed locally in the parenchyma of this organ (Fig. 1E).

\section{Perianth}

The surface of the epidermis varies in different parts of the perianth. The apical part of the tepals is covered by elongated epidermal cells with convex outer walls (Fig. 2A, B). Conical papillae, $13.3 \mu \mathrm{m}$ high and $13.2 \mu \mathrm{m}$ wide at the base, were observed on the surface of epidermal cells in the middle and lower part of these organs. Secretion was visible at the tip of the papillae beneath the cuticle and on its surface (Fig. 2G). Small papillae were also observed on the surface of the cells in the upper region of the perianth tube (Fig. 2C, F). The outer wall surface of these cells showed distinct striation of the cuticle. There was a great density of longer hairs on the perianth surface at the base of the filaments (Fig. 2C, E). Glandular trichomes with small spherical protrusions at the tip and more elongated non-glandular trichomes were distinguished here (153.3-427.9 $\mu \mathrm{m})$. In the glandular trichomes, the cytoplasm and cell sap stained with toluidine blue (Fig. 2H), whereas the non-glandular trichomes remained unstained (Fig. 2I).

In the cross-sectional view of the tepals, the papillae were visible both in the adaxial and abaxial epidermis (Fig. 3A, B). The outer walls of the adaxial epidermal cells were thicker than those in the abaxial epidermis (Fig. 3A-D). The nuclei in the cells of both epidermal layers were large and lobate (Fig. 3A). Accumulated secretion was observed in the apical parts of the papille, beneath the protruding cuticle (Fig. 3B). In some cells of the adaxial epidermis, both in the cytoplasm located in their basal part and near the outer wall of the papillae, there were concentrations of a fluorescent substance, viewed under the fluorescence microscope (Fig. 3E). Small, fluorescent granular structures were also observed at places on the outer wall surface of the papillae. Such varied contents of the epidermal cells may be evidence of their asynchronous functioning.

The adaxial surface of the perianth tube was covered by an epidermis composed of long cells with convex anticlinal walls. Moreover, the sculpturing of the surface in this region, which came into contact with the nectar accumulated in the flowers, was formed by small cuticular striae running crosswise and longitudinally (Fig. 2D). Small papillae were found in the adaxial epidermis in the upper part of the tube (Fig. 2 F).

In the cross-sectional view, the epidermis of the perianth tube was composed of small cells. Collenchy- ma was the reinforcing layer. There were $14-15$ vascular bundles in the perianth tube. Large intercellular spaces were observed in the parenchyma in the upper portion of the tube (Fig. 6A).

\section{Stamens}

The filaments, flattened and depressed in the middle part (Fig. 4A, B), were distinguished by a longitudinally striated cuticle of the epidermal cells and by the presence of papillae of different height (11.6-27.9 $\mu \mathrm{m}$ ) (Fig. 4D, F). In the depressed section of the filament, particular epidermal cells formed 2-4 small papillae (Fig. 4D, F). The apical portion of the anthers was covered by elongated epidermal cells, among which no stomata were observed (Fig. 4C). Remnants of the tapetum were observed on the inner surfaces of the pollen chambers in the empty anthers (Fig. 4E).

Spherical pollen grains of $C$. vernus averaged $103.9 \mu \mathrm{m}$. These grains were inaperturate, with a thick layer of intine and a much thinner layer of exine. $\mathrm{Nu}$ merous yellow tryphine droplets were observed on the surface of the pollen grains (Fig. 4G, H). Pollen viability was $79 \%$.

\section{Pistil}

In its upper part, the style branches out into 3 branches. Each of them has the shape of a funnel open on its side and irregularly incised from the top (Fig. 5A). The highest located parts of the style branches are flattened and strongly folded, while their apical portions are densely covered by papillae (Fig. 5B, $\mathrm{C}, \mathrm{E}, \mathrm{F})$. The region producing papillae is the stigma of the pistil. The papillae of the stigma are appendages that are cylinder-shaped or expanded at the tip (Fig. 5B, C, E, F). In the upper region of the style, below the stigma, vesicular protrusions of the cuticle could be seen (Fig. 5B). At the end of anthesis, the surface of the papillae became strongly folded (Fig. 5C). The epidermal cells of the style were strongly elongated and marked by the presence of a striated cuticle (Fig. 5D).

Along a long section, the style is surrounded by the perianth tube which adheres quite tightly to the style (Fig. 6A-C). A narrow space is formed between these organs (Fig. 6A), which is filled by the nectar flowing up to the upper part of the flower. In the lower and middle part of the style, three stylar channels are found and they become fused in the upper portion of the style (Fig. 6C). Calcium oxalate crystals in the form of raphides and numerous plastids were observed in the parenchymal cells surrounding the channels (Fig. 6D, F).

Numerous ovules found in the lower three-chambered ovary showed characteristic fluorescence in some of their parts under the fluorescent microscope (Fig. 6E). 

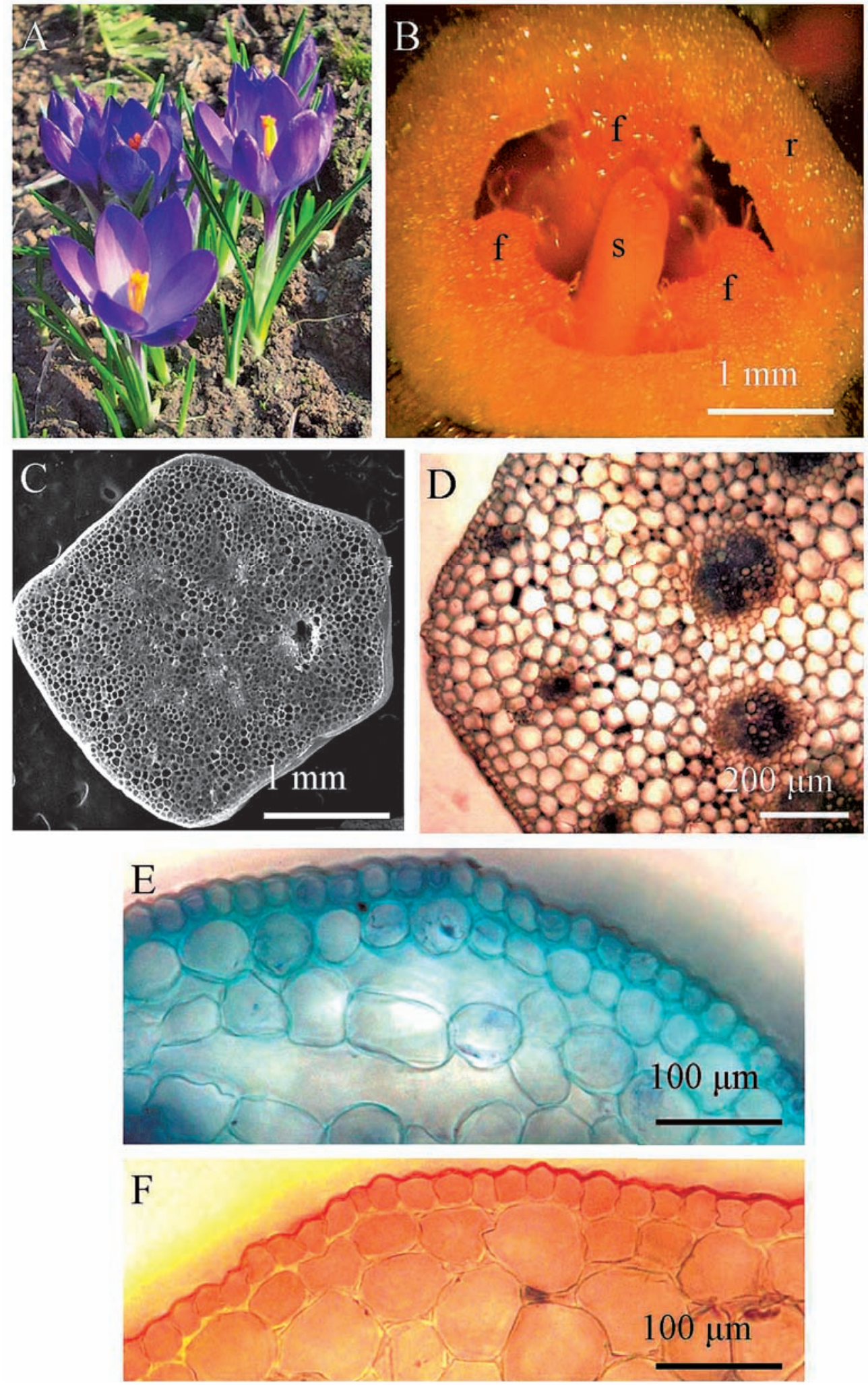

Fig. 1. Crocus vernus flowers and their photos: A - flowering plants; $\mathrm{B}$ - cross section of the perianth tube (r), attached filaments (f), and the style of the pistil (s); C, D - cross sections of the flower stalk; E, F - outer tissues of the stalk (E - methylene blue staining, F - Sudan III staining). 

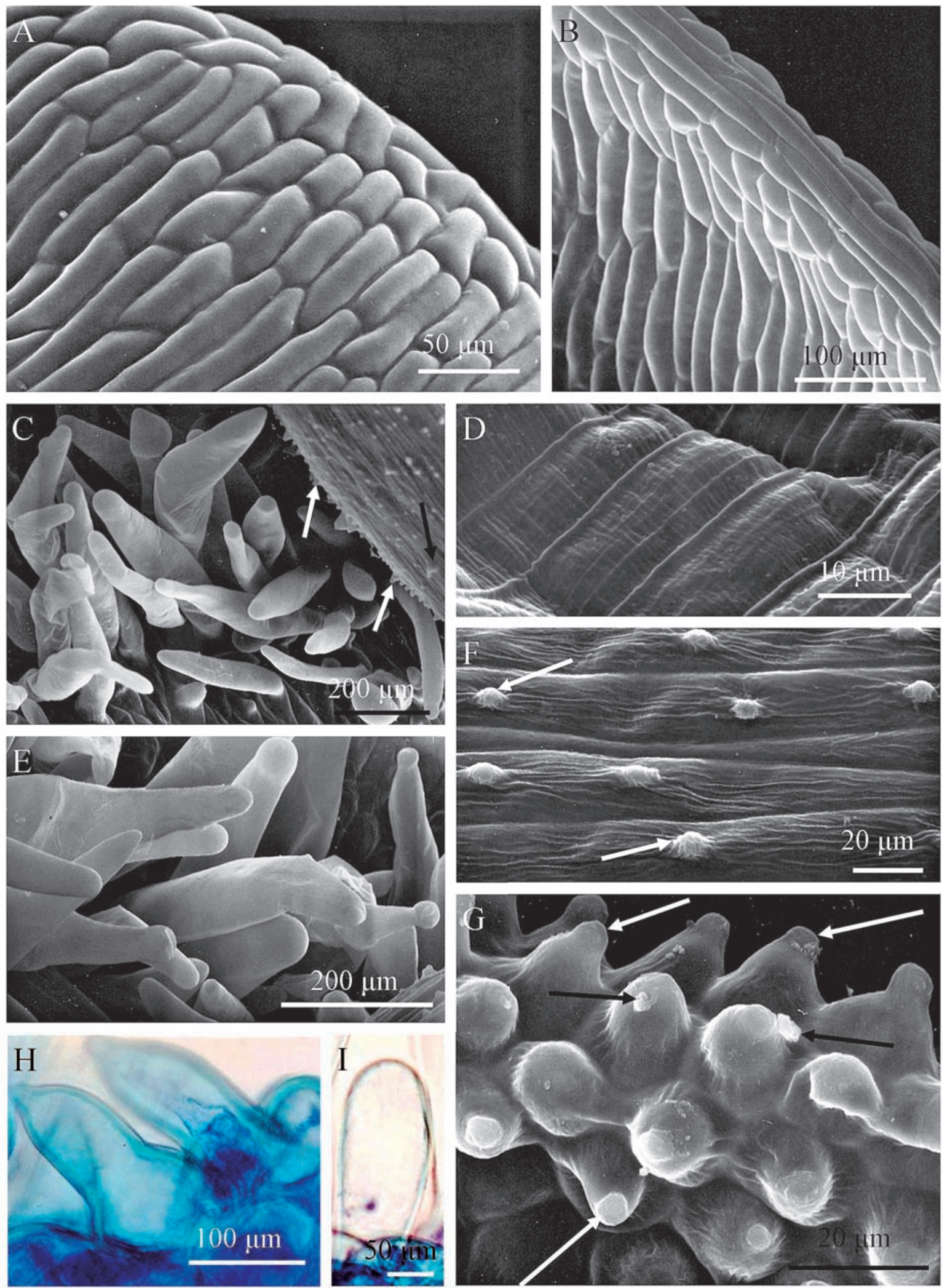

Fig. 2. Surface portions of Crocus vernus perianth segments: A, B - apical part of tepals; C, E, - glandular and non-glandular trichomes from the apical part of the perianth tube; visible small papillae in fig. C (arrows); D - adaxial epidermis from the lower part of the perianth tube; $\mathrm{F}$ - adaxial epidermis from the upper part of the perianth tube, papillae (arrows); $\mathrm{G}$ - papillae (arrows) in the adaxial epidermis of the tepals; $\mathrm{H}$ - glandular trichomes stained with toluidine blue; I - Apical part nonglandular trichome showing not staining after treatment with toluidine blue. 

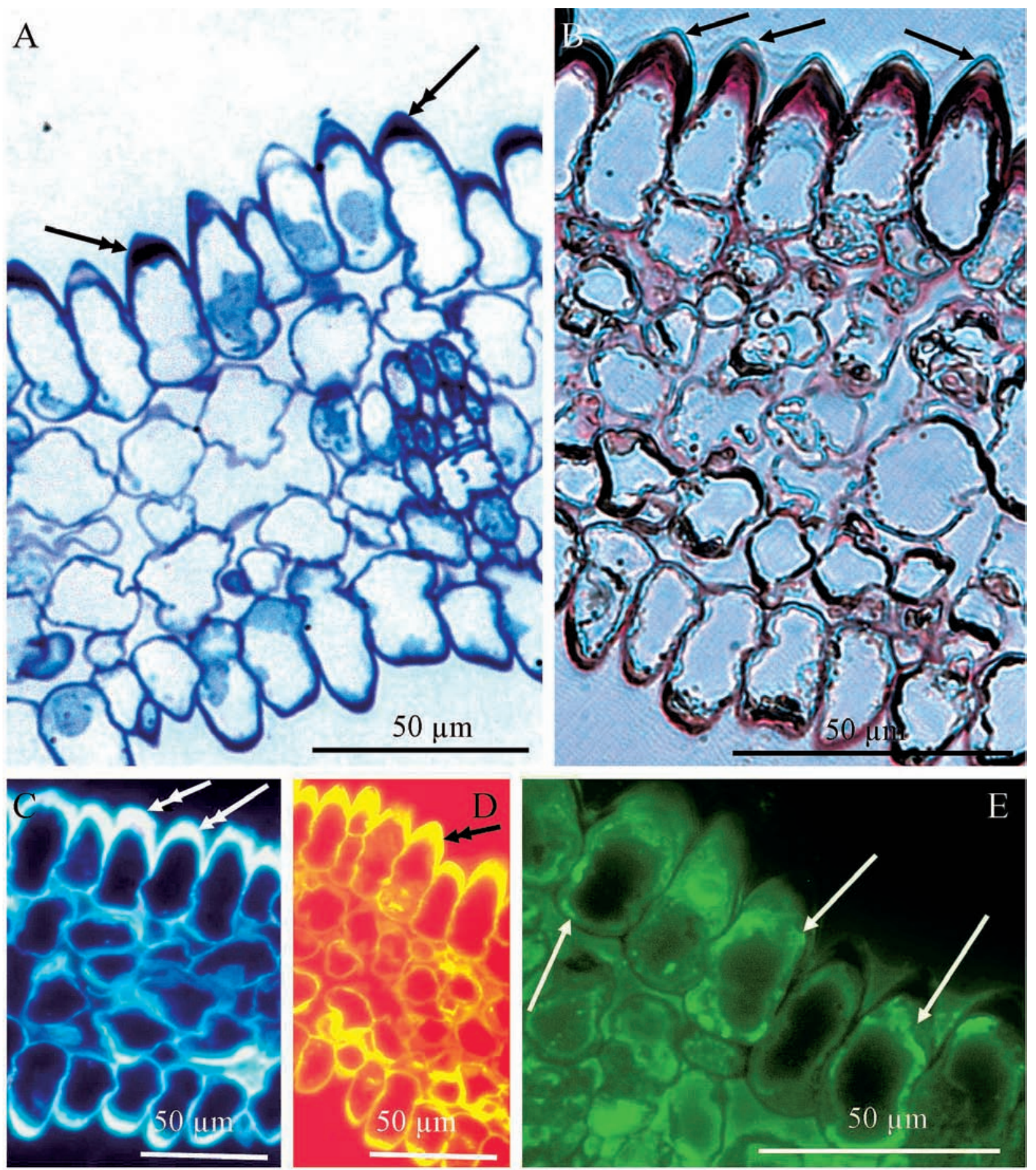

Fig. 3. Cross sections of Crocus vernus tepals with papillae in the adaxial and abaxial epidermis: A - section stained with toluidine blue. Double-headed arrows show the thickened walls of the papillae in the adaxial epidermis; B - section stained with ruthenium red, arrows show accumulated secretion; C, D - cross sections viewed under a fluorescence microscope, thickened walls of the papillae in the adaxial epidermis (double-headed arrows) (C - with DAPI filter, D - with TRITC filter); $\mathrm{E}$ - papillae of the adaxial epidermis with a substance in the cytoplasm showing fluorescence (arrows) under a fluorescence microscope (with FITC filter). 

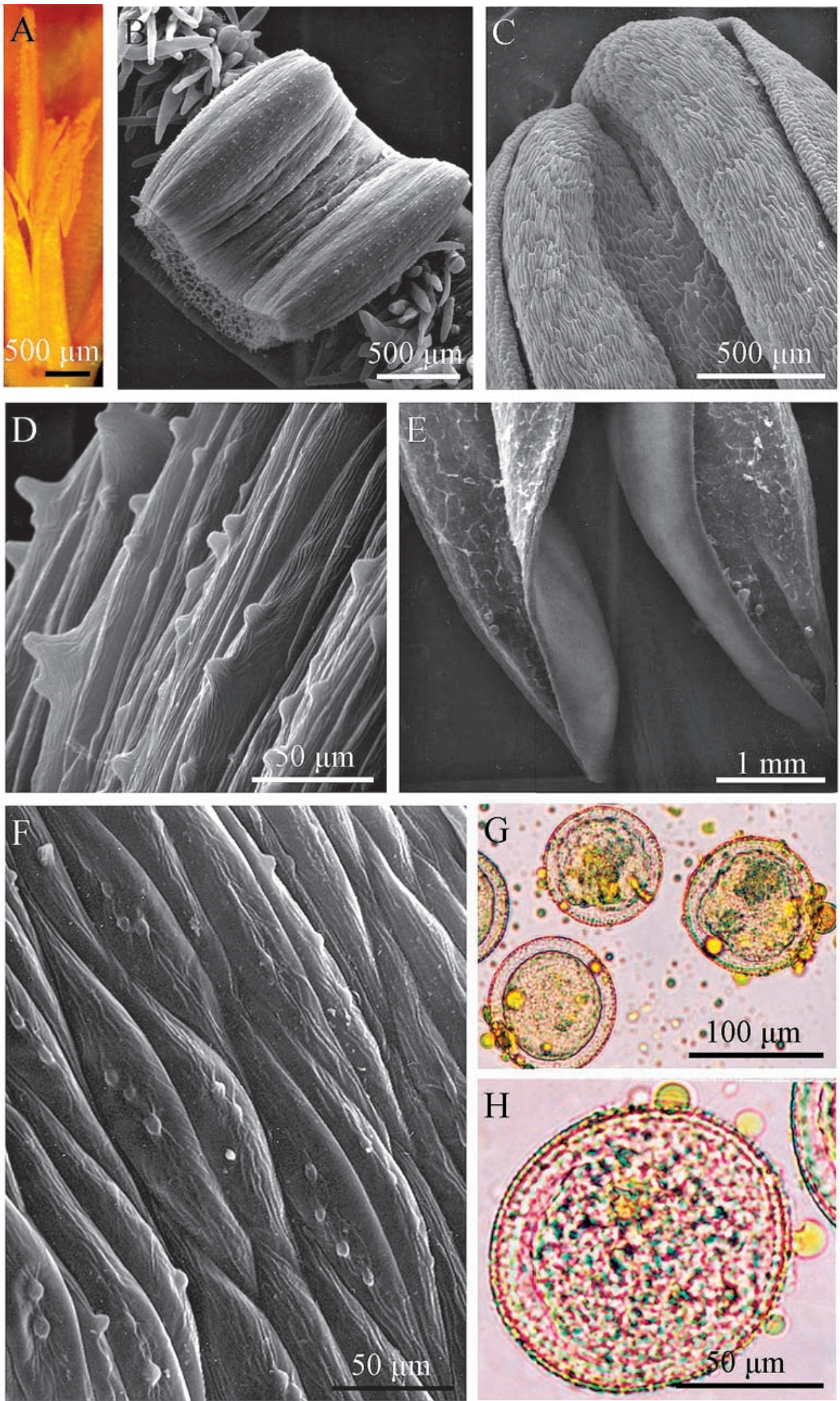

Fig. 4. Parts of C. vernus stamens and pollen grains: A - part of a flower with a stamen; B - portion of a filament and numerous trichomes occurring near the perianth tube; $\mathrm{C}$ - upper part of anthers; D - lateral part of a filament; $\mathrm{E}$ - parts of empty pollen chambers; F - epidermal cells of a filament with 2-4 papillae; $\mathrm{G}, \mathrm{H}$ - pollen grains with tryphine droplets. 

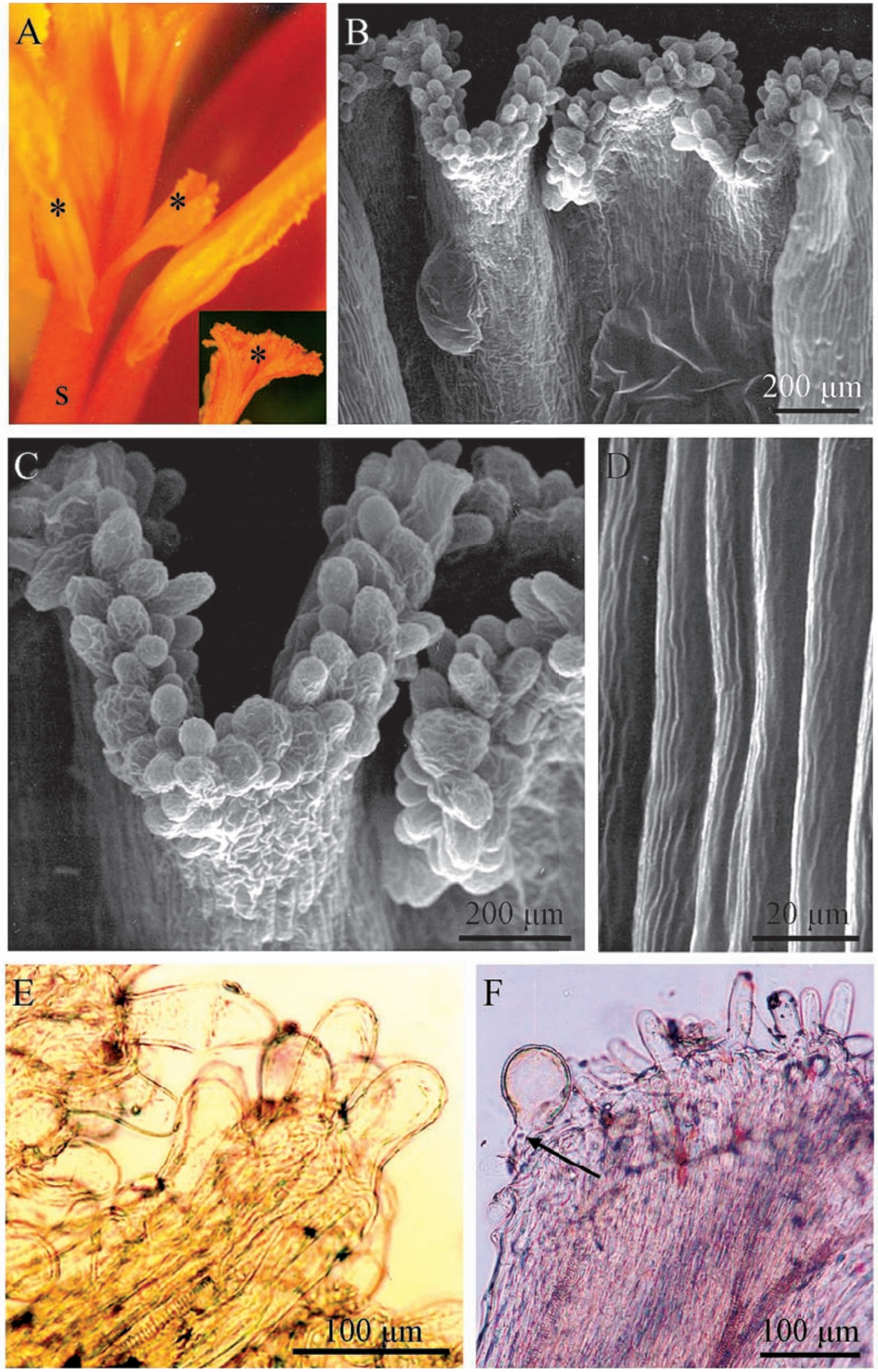

Fig. 5. Upper parts of the style and stigmas of the pistil in C. vernus: A - intensely coloured stamens and the style (s) with stigmas (stars); B , C - papillae on the stigmas (SEM); D - elongated epidermal cells of the style with striated cuticular ornamentation (SEM); E, F - papillae on the stigmas, pollen grains with the pollen tube (arow) being formed are visible on the left side. 

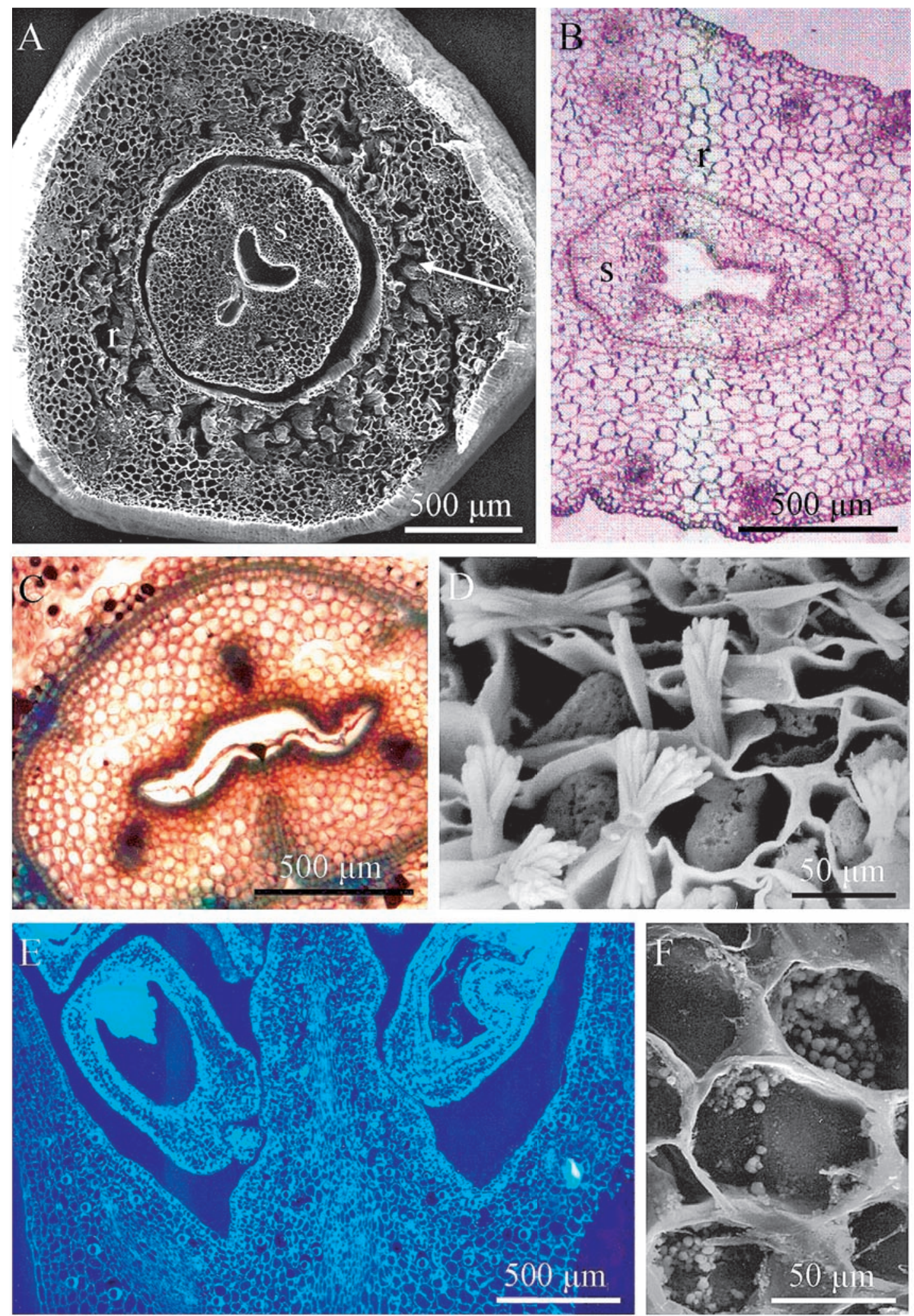

Fig. 6. Cross sections of the style and the ovary of the pistil in C. vernus: A - cross section of the style (s) surrounded by the perianth tube (r), visible large intercellular spaces in the parenchyma of the perianth tube (arrow), (SEM); B - cross section of the perianth tube (r) with the style (s) (LM); C - cross section of the style with a flattened stylar channel; D - calcium oxalate raphides from the parenchymal cells surrounding the stylar channel; E - portion of longitudinal section of the ovary (FM); $\mathrm{F}$-parenchymal cells in the style with numerous plastids. 


\section{DISCUSSION}

Maurizio and Grafl (1969) classify the flowers of Crocus as funnel-shaped flowers which close in cold and cloudy weather. S z a fer and $\mathrm{Woj}$ tusiakowa (1969) report that flowers of various Crocus species are pollinated by hymenopterans and lepidopterans. As butterfly flowers, they are included in the group of transitional flowers due to the perianth that is open during the day and at dusk, which allows pollination by butterflies and moths. Such flowers are characterized by a large range of colours, from very bright to dark, and they often have contrastingly coloured perianth segments.

K u g l e r (1970) includes flowers of plants of the genus Crocus in the group of proper flowers pollinated by bees and bumblebees. P r o c t o r et al. (1996) report that the stamens and the pistil form in these flowers a column on which bees visiting the flowers land.

Our observations show that the life span of the C. vernus flower is 3-3.5 days. But $\mathrm{K} \mathrm{u} \mathrm{g} \mathrm{le} \mathrm{r} \mathrm{(1970)}$ reports that the Crocus sativus flower blooms for 12 days. The above-mentioned author claims that the intensity of odorous substances emitted by $C$. albus flowers increases in the direction of the base of the free perianth segments.

In $C$. vernus, we observed glandular papillae on both sides of the tepals as well as hairs located in the upper part of the tube. The presence of the glandular papillae on both sides of the tepals indicates the possibility of emitting odours by the upper and lower surface of these organs. Other authors have shown in the flowers of Rosa x hybrida that the epidermal cells occurring on both sides of the petals produce odorous compounds (B e rg o u g n o u x et al. 2007).

Numerous small papillae also formed in the epidermal cells of the filaments. 2-4 papillae were observed in individual cells. All these structures may participate in the emission of odorous compounds. In the apical part of the papillae of the perianth, we observed in SEM, but also under the light and fluorescent microscopes, secretion that accumulated beneath the cuticle and was released onto its surface. Odour emission by the papille of the perianth epidermis has been found many times in various species ( $\mathrm{V} \mathrm{ogel}$, 1990; S t pi czy ń ska，2001; B ergougnoux, 2007; W eryszko-Chmielewska and Chwil, 2011). It has also been found that the papillae on the perianth surface can increase the intensity of flower colour and petal reflex as well as humidity and temperature inside the flower (Whitney et al. 2011). In our earlier study on Asphodellus, we found the location of the tissue producing essential oils also on the filaments (Wery s z k o- C h mi e lew s ka et al. 2007).
On the stigma of the pistil in Crocus vernus, we observed cylindrical papillae whose cuticle was smooth at the beginning of flowering and markedly wrinkled at the end of anthesis. Germinating pollen grains were also visible on the stigmas. Chichiric co (1990) reports that a dry stigma occurs in C. vernus and that the germinating pollen tubes penetrate into the cuticle of the papillae along the cell wall, making their way toward the stigma lobes, and then toward the style. According to this author, there is a high degree of allogamy in C. vernus, and the barrier of self-incompatibility is within the ovary.

The diameter of the measured $C$. vernus pollen grains was $103.9 \mu \mathrm{m}$, whereas B e ug (2004) gives the extreme values for the size of pollen grains in this species in the range of 70.8-107.5 $\mu \mathrm{m}$, with the average value of $90.4 \mu \mathrm{m}$. This author emphasises that due to the large dimensions of these pollen grains and a relatively thin exine $(1-1.5 \mu \mathrm{m})$, these grains are easily deformed.

\section{REFERENCES}

Arslan N., Ozer A. S., Akdemir R., 2009. Cultivation of saffron (Crocus sativus L.) and effects of organic fertilizers to the flower yield. Acta Hortic. 826: 237-240.

Bergougnoux V., Caissard J. C., Jullien F., Magnard J. L., Scalliet G., Cock J. M., Hugueney P., Baudino S., 2007. Both the adaxial epidermal layers of the rose petal emit volatile scent compounds. Planta, 226: 853-66.

Beug H.J., 2004. Leitfaden der Pollenbestimmung. Verlag Dr Friedrich Pfeil, München (in German)

Ch i ch i r i c co G., 1990. Self-incompatibity in Crocus vernus ssp. vernus. (Iridaceae). Plant Syst. Evol. 172: 77-82.

Dalby R., 2000. A trio of spring bee plants: prairie crocus, skunk cabbage, and manzanita. Am. Bee J. 140(2): 147-149.

H l a v a B ., 1984. Rośliny kosmetyczne. Warszawa, Państwowe Wydawnicywo Rolnicze i Leśne, (in Polish)

Jaroszyńska T., 1992. Atrakcyjność krokusów (Crocus sp.) dla pszczół. / Attractiveness of crocuses (Crocus sp.) for bees. XXIX Naukowa Konferencja Pszczelarska. Streszczenia referatów. Puławy 8-9 kwietnia: 10-11, (in Polish)

Kohlmünzer S., 1997. Farmakognozja. Podręcznik dla studentów farmacji. Warszawa, Wydawnictwo Lekarskie PZWiL. (in Polish).

Kołtowski Z., 2006. Wielki atlas roślin miododajnych. Warszawa, Przedsiębiorstwo Wydawnicze Rzeczpospolita. (in Polish).

Krause J., 2002. Kwiaty cebulowe. Warszawa, Wydawnictwo „Działkowiec”. (in Polish).

Kugler H., 1970. Blütenökologie. Gustar Fischer Verlag, Stuttgart, (in German) 
Mabberly D.J., 1997. The plant-book: a portable dictionary of the higher plants. Cambridge University Press, Cambridge, UK.

Makhlouf H., Saksouk M., Habib J., Chahine R., 2011. Determination of antioxidant activity of saffron taken from the flower of Crocus sativus grown in Lebanon. Afr. J. Biotech. 10 (41): 8093-8100.

Maurizio A., Grafl I., 1969. Das Trachtpflanzenbuch. Ehrenwirth Verlag, München, (in German)

Mehrl N., 1987. Garden plants as bee pasture. Gartenpflanzen als Bienenweide. Staudengarten. 1986(3): 28-37.

Mölzer V., 1983. Kwitnący ogród. Warszawa, Państwowe Wydawnictwo Rolnicze i Leśne. (in Polish).

Morag a A.R., Fernández Nohales P. F., Fernandez Perez J. A. Gomez-Gomez L. 2004. Glucosylation of the saffron apocarotenoid crocetin by a glucosyltransferase isolated from Crocus sativus stigmas. Planta. 219(6): 955-966.

Namin M.H., Ebrahimzadeh H., Ghareyazie B., Radjabian T., Namin H.H., 2010. Initiatio and origin of stigma-like structures (SLS) on ovary and style explants of saffron in tissue culture. Acta Biol. Crac., Ser. Bot. 52(1): 55-60.

O s z k in is K., 1994. Kwiaty od A do Z. Warszawa, Państwowe Wydawnictwo Rolnicze i Leśne. (in Polish).

Piękoś-Mirkowa H., Mirek Z., 2007 Rośliny górskie. Warszawa, MULTICO Oficyna Wydawnicza. (in Polish).

Podbielkowski Z., 1980. Słownik roślin użytkowych. Warszawa, Państwowe Wydawnictwo Rolnicze i Leśne. (in Polish).

Podbielkowski Z., 1992. Rośliny użytkowe. Warszawa, Wydawnictwa Szkolne i Pedagogiczne. (in Polish).

Proctor A., Yeo P., Lack A., 1996. The natural history of pollination. Collins Publishers, London.

Radjabian T., Saboora A., Naderimanesh H., Ebrahimzadeh H., 2001. Comparative analysis of crocetin and its glycosyl esters from Crocus sativus L. and Crocus haussknechtii Boiss. as an alternative source of saffron. J. Food Sci. J. Food Sci. Technol. (Myosore). 38(4): 324-328.

Rejewski M., 1992. Rośliny przyprawowe i używki roślinne. Warszawa, Państwowe Wydawnictwo Rolnicze i Leśne. (in Polish).

Rutkowski L., 2008. Klucz do oznaczania roślin naczyniowych Polski niżowej. Warszawa, Wydawnictwo Naukowe PWN. (in Polish).

Spiczyńska M., 2001. Osmophores of the fragrant orchid Gymnadenia conopsea L. (Orchidacea). Acta Soc. Bot. Pol. 70 (2): 91-96.

Strzelecka H., Kowalski J., 2000. Encyklopedia zielarstwa i ziołolecznictwa. Warszawa, Wydawnictwo Naukowe PWN. (in Polish).

Szafer W., Wojtusiakowa H., 1969. Kwiaty i zwierzęta. Państwowe Wydawnictwo Naukowe, Warszawa. (in Polish).

S zweykows cy A. J., 2003. Słownik botaniczny. Warszawa, Wiedza Powszechna. (in Polish).
Vogel S., 1990. The role of scent glands in pollination: on the structure and function of osmophores. Amerind Publishing Co., New Delhi, India.

Weryszko-Chmielewska E., Chwil M., 2011. Micromorphology of the floral elements, the structure of the nectary, and the apicultural value of Elaeagnus commutate Bernh. ex Rydb. Acta Agrobot. 64 (1): 27-34.

Weryszko-Chmielewska E., Chwil M., Sawidis T., 2007. Micromorphology and histochemical traits of staminal osmophores in Asphodelus aestivus Brot. flower. Acta Agrobot. 60(1): 13-23.

Whitney H.,M., Bennett K.M.V., Dorling M., Sandbach L., Prince D., Chittka L., Glover B. J., 2011. Why do so many petals have conical epidermal cells? Ann. Bot. 108: 609-616.

Zhang Y., Tan D., 2009. Breeding system and pollination biology of Crocus alatavicus (Iridaceae), a geocarpic subalpine plant of the western Tianshan Mountains. Biodivers. Sci. 17(5): 468-475.

\section{Struktura elementów kwiatowych Crocus vernus L. Hill}

\section{Streszczenie}

W warunkach klimatycznych Lublina Crocus vernus kwitnie od trzeciej dekady marca do trzeciej dekady kwietnia. Kwiaty żyją 3-4 dni. Badania mikromorfologii listków i rurki okwiatu oraz pręcików i słupka przeprowadzono w skaningowym mikroskopie elektronowym. Cechy anatomiczne elementów okwiatu i łodyżki kwiatowej badano przy użyciu mikroskopii świetlnej i fluorescencyjnej. Ziarna pyłku obserwowano w mikroskopie świetlnym. Stwierdzono, że komórki epidermy doosiowej i odosiowej w środkowej i dolnej części listków okwiatu tworzą papillle. Znacznie mniejsze papille powstają $\mathrm{w}$ górnej strefie rurki okwiatu. Przy nasadach nitek pręcikowych występują wydłużone włoski mechaniczne i wydzielnicze zkulistymiuwypukleniaminaszczycie. Nitkipręcikowe wyróżniają się komórkami epidermy z podłużnie prążkowaną kutykulą i obecnością papilli o różnej liczbie i wielkości. Walcowate papille na znamieniu słupka okrywa pomarszczona kutykula. Szyjka słupka otoczona jest na znacznej długości przez rurkę okwiatu. Między tymi organami tworzy się wąska przestrzeń, którą wypełnia nektar. W szyjce słupka występują kanały stylarne. W komórkach parenchymy otaczających kanały obserwowaliśmy kryształy szczawianu wapnia i liczne plastydy. Bezaperturowe, kuliste ziarna pyłku pokryte są licznymi kroplami kitu pyłkowego. W pracy dyskutowane są funkcje papilli występujących w epidermie okwiatu i nitek pręcików. 
